\title{
APPLYING OUTSOURCING In EgYPTIAN Hotels: A Field STUdy ON A SAMPLE OF Five STAR IN HotelS SHARM EL-SHEIKH CITY
}

\author{
By \\ Ahmed Anwar Elsaed \\ Assistant Lecturer , Hotels Studies Deparatment \\ Faculty of Tourism and Hotels, Mansoura University $\square$
}

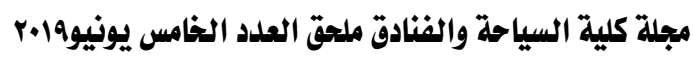

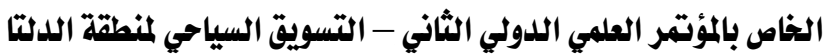


Applying Outsourcing in Egyptian Hotels: A Field Study

— on a Sample of Five Star in Hotels Sharm El-Sheikh City

Applying Outsourcing in Egyptian Hotels: A

Field STUdy ON A SAMPLE OF FIVE STAR IN HOTELS

SHARM EL-SHEIKH CITY

\section{Abstract}

Ahmed Anwar Elsaed ${ }^{1}$

This study aims to explore the extent of applying outsourcing in a sample of Sharm El-Sheikh hotels and identify the benefits and barriers of applying outsourcing in Egyptian hotel market. In order to achieve these objectives, a questionnaire form was developed and directed to a random sample of divisions' and department managers in a five star hotels. A total of 420 questionnaires were distributed among them; only 391 forms (93.1\%) were valid. The obtained results indicated that the majority of hotels (68.7\%) were outsource their activities partially for reducing the need of capital which spent on non-core activities as the main reason (mean= 4.58). Hotels faced difficulty in monitoring vendors and controlling over the activities which outsourced as the main barriers of applying outsourcing (mean= 4.70). Hotel policies and its culture ranked as the main factors affecting on outsourcing decision taking (mean= 4.77). Based upon the findings, some recommendations were suggested and directed to both of hotel managers and suppliers.

Key Words: Hotel Industry, Outsourcing, Core Activities, Suppliers. 


\section{تطبيق التعهيد في الفنادق المرية: دراسة هيدانية علي عينة هن فنادق الخمس نهوم بمدينة شرم الشيخ}

|ll| (1)

تهدف تلك الدراسـة إلي معرفة مدي تطبيق التعهيد بالفنادق المصرية من

خلال عينة من فنادق الخمس نجوم بمدينة شرم الشيخ، وتحديد كلا من فوائد و معوقات تطبيق التعهيد ِيخ القطاع الفندقي المصري. من أجل تحقيق الهدف من الدراسلة، تم توزيـع إستمـارة إستبيان علي عينـة عشوائية من مديري الأقسسام و الإدارات المختلفة داخل فنادق الخمس نجوم بمدينـة شرم الشيخ. تم توزيع ·rع إستمارة، كان منهمه اqه إستهارة (1.به٪) فقط صالحين للتحليل الإحصائي. تشير النتائج أن أغلب الفنادق عينة الدراسة (1.v٪) تعهد أنشطتها بشكل جزئي بهدف تقليل رأس المال المخصص كلأنثطة الغير أسساسية كسبب رئيسي (بمتوسط= 01.4 ). تمثل صعوبة

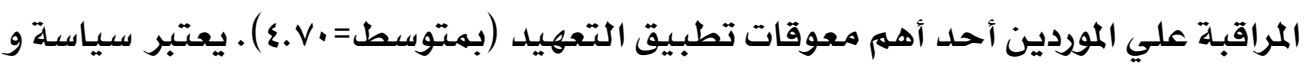
ثقافة الفندق هو أحد العوامل الرئيسية التي تؤثر فِ إتخاذ قرار التعهيد (بهتوسط=VV.ع). بناء علي النتائج المستخلصة، تم وضع مجموعة من التوصيات موجهة لكلا من الموردين و مديري الفنادق الكالمات الدالة: صناعة الفنادق، التعهيد، الأنشطة الأسـاسية، الموردين

\section{Introduction}

Outsourcing considered one of the management practices which intend to depend on specialized suppliers in performing some hotel activities to guests. In addition to that, it is one of the proposed strategies to hotel management which have an important role in reducing costs and improving the quality (Bolat and Yilmaz, 2009; Promsivapallop, Jones and Roper, 2015). Lamminmaki (2011), stated that in recent years, it noticed that an exponentially grown of using outsourcing technique with many 
Applying Outsourcing in Egyptian Hotels: A Field Study

= on a Sample of Five Star in Hotels Sharm El-Sheikh City

forecasts of continued growth. Hotel management can apply outsourcing in many departments or activities. Laundry, security, gardening, animation and public relations are a sample of these activities (Smith, 2012). Hotels might outsource also transportation services, staff recruitment, concierge and much more (Hiamey and Amenumey, 2013).

\section{Research aim}

This research aims to explore the extent of applying outsourcing in a sample of five star hotels in Sharm El-Sheikh city and identify the benefits and barriers of applying outsourcing and factors affects taking the decision of implementation outsourcing in Egyptian hotel market.

\section{Research questions}

1) To what extent the investigaed hotels implement outsourcing practices in current activities?

2) What is the current/prospective status of applying outsourcing in hotel departments?

3) What are benefits of applying outsourcing in hotels?

4) What are barriers of applying outsourcing in hotel?

5) What are the factors that affects taking the decision of implementation outsourcing in hotel?

\section{Research hypotheses}

Based on the researcher's reading about the subject of hotel outsourcing, the study hypotheses could be suggested as follows:

Hypothesis 1: There are significant differences on 0.05 degree between the views of managers on using outsourcing practices in their hotels returns to their demographical data (educational level and years of experience).

Hypothesis 2: There is a significant positive relationship on 0.05 degree between (benefits, obstacles, and factors affects) of applying hotel outsourcing and the current/future status of outsourced activities in Sharm El-sheikh hotels. 
H1: Variance

H2: Correlation

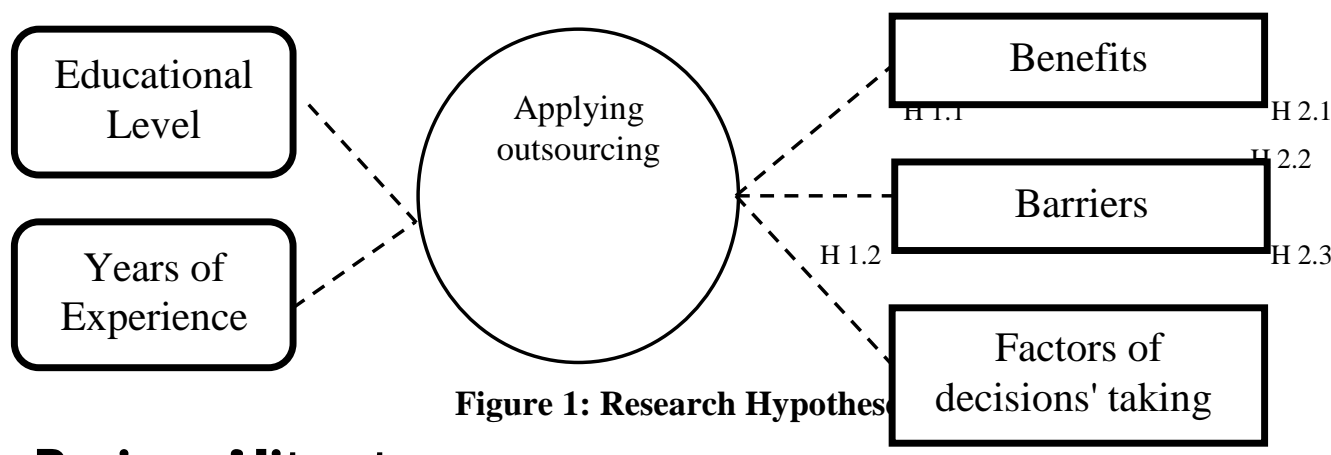

\section{Review of literature}

Figure 1: Research Hypothes decisions' taking

\section{An Overview of the Hotel Outsourcing}

According to Calik, Batman, and Kingir (2013), Outsourcing in hotel industry started from twenty years ago by given some hotel activities to specialized companies to accomplish. In recent, outsourcing considers as an adopted strategy in hotels that aims to reduce costs and risks moreover, increasing revenues and improving productivity. From managers' points of view, outsourcing practices in hotel industry will grow in the future (Hiamey and Amenumey, 2013).

Almost, the majority of researchers addressed outsourcing in their literatures as a problem that needs to be investigated. With the differentiation of research's' problems, varied understanding of outsourcing has been developed (Galahitiyawe, 2013). Therefore, Table 1 summerized a collective summary of different definitions of outsourcing that recorded from various authors and researchers whose addressed to context of hotels.

Table 1: Definitions of Outsourcing

\begin{tabular}{|l|l|}
\hline \multicolumn{1}{|c|}{ Author/Year } & \multicolumn{1}{c|}{ Definition } \\
\hline $\begin{array}{l}\text { Espino-Rodriguez } \\
\text { and Padron- } \\
\text { Robaina (2006) }\end{array}$ & $\begin{array}{l}\text { "Outsourcing is a strategic decision } \\
\text { that entail the external contracting of } \\
\text { transferring non-core activities to } \\
\text { higher capability firms to undertake } \\
\text { those activities ". }\end{array}$ \\
\hline
\end{tabular}


Applying Outsourcing in Egyptian Hotels: A Field Study

- on a Sample of Five Star in Hotels Sharm El-Sheikh City

\begin{tabular}{|l|l|}
\hline Kancharlan (2007) & $\begin{array}{l}\text { Outsourcing is simply describes a } \\
\text { situation where the establishment } \\
\text { leaves part of its work to other } \\
\text { company which has an ability to } \\
\text { execute its mission efficiently with } \\
\text { lower cost. }\end{array}$ \\
\hline $\begin{array}{l}\text { Galahitiyawe } \\
\text { (2013). }\end{array}$ & $\begin{array}{l}\text { Outsourcing is a process of } \\
\text { transferring an internal work (client) } \\
\text { to external place (outsourcer)". }\end{array}$ \\
\hline $\begin{array}{l}\text { Sani, Dezdar, and } \\
\text { Ainin (2013) }\end{array}$ & $\begin{array}{l}\text { Outsourcing considered a } \\
\text { subcontracting service that useful in } \\
\text { generating the value of firms and } \\
\text { increasing competitive advantage. }\end{array}$ \\
\hline
\end{tabular}

\section{Classifications of Hotel Outsourcing}

Promsivapallop (2009) referred to that according to range, outsourcing can be divided to total or full outsourcing and partial or specified outsourcing. Many organizations find that total outsourcing is a good option for them specially in some departments or activities. For instance, hotels' management may prefer to full outsource some departments such as security department by depending on specialized company to perform the whole operation (Sriwongwanna, 2009). On other hand, other organizations prefer to apply partial or selective outsourcing in their activities. For example, laundry function in the hotel can be transfer to external company while keeping other housekeeping functions in-house (Hiamey and Amenumey, 2013).

Promsivapallop (2009) stated that outsourcing practices classified according to the nature of work to project-oriented and process-oriented outsourcing. Project-oriented outsourcing can be applied in unique, non-standardized and non-routine work. An example of that, software or website updates. On other hand, process-oriented outsourcing involves a standardized, well- 
structured and documented functions, for instance, outsourcing of a payroll function (Vitasek, Ledyard, and Manrodt, 2013).

Power et al., (2006) postulated that Outsourcing can be classified by location of work to off-site outsourcing and on-site outsourcing. Off-site work is the case when the outsourcing providers perform their works at their location and not necessary to provide their services inside the organization (i.e. hotels). For example, recruiting function. On other hand, on-site outsourcing involves performing the service or product within the organization. In this case, the organization has members of the service provider's staff. Security department in hotel considers as one of the on-site outsourcing examples.

Sriwongwanna (2009) presented another classification of outsourcing based on the level of required expertise. The researcher classified outsourcing in this case to transitional outsourcing and transformational outsourcing. The reason behind the selection of transitional outsourcing is limited resources to interest in antiquated activities or updating technology in the organization. Absolutely, some hotels have limited resources (e.g. capital, building size, and employees' skills). Hence, this option can be the best solution for those hotels. On other hand, the organization's aim of using transformational outsourcing is to develop their activities in order to enhance their employees' skills and improve their capabilities. The best example of transformational outsourcing is external training (Vitasek et al., 2013).

According to the level of decision analysis, it could be segmented outsourcing by two parts "tactical outsourcing and strategic outsourcing. Tactical work considers a very simple work rather than strategic outsourcing. The decision of taken tactical outsourcing is based on reducing costs with no interesting of the other advantages or disadvantage of taken this decision. In this case, the management is interested in performing its activities at a 
Applying Outsourcing in Egyptian Hotels: A Field Study

- on a Sample of Five Star in Hotels Sharm El-Sheikh City

lower costs due to organization's budget. Meanwhile, The main objectives of strategic outsourcing are to focus on core and noncore activities and to make improvement in the organization's performance (e.g. adding new technology, changes in operation process, and increasing productivity) (Sirec, Rebernik, and Hojnik, 2012; Vagadia, 2012).

\section{Benefits of Hotel Outsourcing}

$\mathrm{Qu}$, Pinsonneault, and Oh (2011) noted that outsourcing provide various benefits to the organization, such as strategic, economic and technological benefits. A simple examples of these benefits are, reducing costs, adding new technology and innovation and improving the organization's performance (Lamminmaki, 2011, Sani et al, 2013; Promsivapallop et al., 2015; Nayak, Pai, Prabhu, and Khurana, 2016).

Outsourcing is a good option for accessing services or products that are not available internally. it enables hotels to overcome the limited resources available in-house. For example, hotels may found difficulty in performing laundry services by itself due to the building size or design (Hiamey and Amenumey, 2013).

Ghodeswar and Vaidyanathan (2008) determined four basic benefits of applying outsourcing in hotels. These advantages involves flexibility, specialization, market discipline and cost saving. These benefits are supplied and discussed in Table 2 as follows:

Table 2: Benefits of Hotel Outsourcing:

\begin{tabular}{|c|c|c|}
\hline Advantage & Definition & Assessment \\
\hline Flexibility & $\begin{array}{l}\text { Performing the } \\
\text { operation easier } \\
\text { either upwards or } \\
\text { downwards at rapid } \\
\text { rate and lower costs }\end{array}$ & $\begin{array}{l}\text { In case of changing in } \\
\text { demand conditions, the } \\
\text { link between the } \\
\text { organization and } \\
\text { suppliers via contracts } \\
\text { can change more quickly }\end{array}$ \\
\hline
\end{tabular}




\begin{tabular}{|c|c|c|}
\hline & & $\begin{array}{l}\text { than other integrated } \\
\text { organizations. }\end{array}$ \\
\hline $\begin{array}{l}\text { Specializati } \\
\text { on }\end{array}$ & $\begin{array}{l}\text { Focusing on core } \\
\text { activities which make } \\
\text { the organization in a } \\
\text { competitive } \\
\text { advantage }\end{array}$ & $\begin{array}{l}\text { Specialization leads to } \\
\text { various } \\
\text { benefits. } \\
\text { organization } \\
\text { more efficient, and value } \\
\text { added is maximized }\end{array}$ \\
\hline Cost saving & $\begin{array}{l}\text { Lower costs than in- } \\
\text { house production }\end{array}$ & $\begin{array}{l}\text { Reducing costs not } \\
\text { necessary lead to lower } \\
\text { quality }\end{array}$ \\
\hline $\begin{array}{c}\text { Market } \\
\text { discipline }\end{array}$ & $\begin{array}{l}\text { Separating purchaser } \\
\text { from the service } \\
\text { provider by formal } \\
\text { contracts }\end{array}$ & $\begin{array}{l}\text { Market discipline } \\
\text { increases the competition } \\
\text { between suppliers, and } \\
\text { organization choices } \\
\text { become based on } \\
\text { purchases and innovation } \\
\text { performance }\end{array}$ \\
\hline
\end{tabular}

Source: Ghodeswar and Vaidyanathan (2008).

Ghodeswar and Vaidyanathan (2008) agreed with Dogerlioglu (2012) result that seasonality and demand fluctuation are the main reasons to implement outsourcing as a significant factor to gain flexibility.

\section{Barriers of Hotel Outsourcing}

Dorasamy, Marimuthu, Jayabalan, Raman, and Kaliannan (2010) have identified some barriers of applying outsourcing which are; supplier failure, change of suppliers circumstance, and loss of confidential information. In the same context, Hamzah, Aman, Maelah, Auzair and Amiruddin (2010) recorded that problems which may occurred when organizations involved in outsourcing include; loss of strategic flexibility, poor quality, loss of core activities, suffering interruption of supply and loss of internal coherence. 
Applying Outsourcing in Egyptian Hotels: A Field Study

= on a Sample of Five Star in Hotels Sharm El-Sheikh City

Hiamey and Amenumey (2013) Illustrated that indirect costs is one of obstacles that face implementing outsourcing. These costs involves transaction costs during choosing suppliers, conversion costs during transferring activities from in-house to out-house and returning activities to in-house if suppliers did not provide the required services.

Hiamey (2012) postulated that in many outsourcing arrangements, the organization's fright of fail owing to cultural mismatch can constitute an impediment to implementing outsourcing. In addition to that, Yilmaz and BedÜk (2014) claimed that is dangerous if hotels tend to outsource core activity. They recommended that core activities should be performed in-house to keep quality and increase guest satisfaction.

\section{Outsourcing practices in hotel departments}

According to Lamminmaki (2003), food and beverages (F\&B) department in hotels have many activities which may be outsourced such as; restaurants, employees' cafeteria, prepreparing ingredients and catering. Also, hotels use outsourcing in F\&B by contracting out with some known / branded restaurants chains as a strategy to gain expertise, competitiveness, and financial stability (Trabulsi, 2017).

Sani et al. (2013) realized that cleaning services is one the most popular activities that use outsourcing in hotels. One of these activities, carpet and windows cleaning functions, pest control, and laundry (Lamminmaki, 2009; Mugassa, 2015; Linen, 2017).

In the context of human resources department, Recruitment companies are more specialized and have advanced technique in reaching to employees such as; web sites, multiple sourcing channels, and recruitment software. They have many followers of applicants, consequently that increased the probability to find the best applicant to the job (Siew-Chen and Seow-Voon, 2016). 


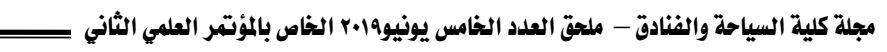

Chan (2012) mentioned that maintenance department could be performed in-house or outsourced to specialized companies, or a combined proportion of both. Hotels would have to outsource any expertise maintenance work that could not performed by inhouse staff (i.e. maintenance for generators). On other hand, when immediate attention is required such as; maintenance of F\&B equipment, in-house staff are suitable to perform that missions (Aryee; 2011; Chan, 2012).

Information technology department (IT) is ideal to outsource in any organization due to its characteristics with highly specialized nature, essential cost, and rapidly changing (Brinkkemper and Jansen, 2012). Hotels preferred to outsource IT department in installing complicated computer programs, such as reservation systems (e.g., Opera, Comsys and Fidelio). On other hand, outsourcing IT carries with some potential risks such as; the lack of control over search engine marketing, loss of contact with guests, and slow updates in the hotel's web-site (Abdullah and Verner, 2012).

Nicholson, Jones, and Espenlaub (2006) believed that accounting outsourcing may be particularly suitable for remote hotels as in these regions it could be difficult to recruit and retain qualified accounting employees. Organizations have outsourced different activities and functions of accounting. These activities may be simple as general accounting or debt management. on other hand, organization could use outsourcing in high level of accounting functions such as payroll, or financial ratio and analysis (Aman and Abdul Rahman, 2011).

In the context of marketing department, Diaz and EspinoRodriguez (2017) suggested to rethink in utilizing outsourcing in sales activities. It should to create new procedures in marketing and sales activities to find a new competitive solution by applying outsourcing. When hotel marketers lose market share and have not the ability to cover an acceptable level of occupancy, in this 
Applying Outsourcing in Egyptian Hotels: A Field Study

= on a Sample of Five Star in Hotels Sharm El-Sheikh City

case hotel needs to find service companies specialized in growing distribution channels.

According to Bolat and Yilmaz (2009), security department is one of the popular functions outsourced in hotels sector. An example of outsourcing security department, a Florida Hilton Hotel outsourced his security functions to Pinkerton Security Company with reducing costs 20\%-30\%. Hotels assigned to specialized training companies to give training courses to all hotel staff about safety and security to be informed about these issues and help security officer in hotel safety (Sani et al., 2013).

\section{Research methodology}

In order to achieve the research aim, divisions' and departmental managers in five star Sharm El-Sheikh hotels were surveyed. A total of 420 questionnaires were distributed randomly in the investigated hotels (20 hotels) during July to September 2018, only 391 forms $(93.1 \%)$ were valid to analyze. The questionnaires were returned and the results then analyzed. The questionnaire consisted of three sections. The first section intended to reveal the managers' demographic data. The second section intended to determine the extent of applying outsourcing in hotels and identify the current/prospective status of outsourcing hotels' departments. The respondents were asked to answer this question by using a three-point Likert-type scale ( yes $=3$, yes to some extent $=2$ and no $=1$ ) to determine the levels of agreement with the departments investigated. The third section included 18 attributes covering the three investigated dimensions (benefits, obstacles, and factors affect) of applying hotel outsourcing. This could be seen in the tables of results. The respondents were asked to answer these questions by using a five-point Likert-type scale (Strongly agree $=5$, agree $=4$, neutral $=3$, disagree $=2$ and strongly disagree $=1$ ) to determine the levels of agreement with the statements investigated. The Statistical Package for the Social 
Sciences (SPSS) version 24.0 was used to analyze and compute the collected data.

The range of each level of agreement was calculated as follow:

$$
\begin{aligned}
& \text { Range }=3-1 / 3= \\
& 0.66 \\
& \mathrm{No}=1 \text { to } 1.66 \\
& \text { Yes to some extent } \\
& = \\
& 1.67 \text { to } 2.33 \\
& \text { Yes }=2.34 \text { to } 3 \\
& \underline{\text { Range }=5-1 / 5=0.8} \\
& \text { Strongly } \quad \underline{\text { Disagree }}= \\
& \text { disagree } \quad 1.81 \text { to } 2.60 \\
& =1 \text { to } 1.80 \\
& \underline{\text { Neutral }}=\quad \underline{\text { Agree }}= \\
& 2.61 \text { to } 3.40 \quad 3.41 \text { to } 4.20 \\
& \underline{\text { Strongly agree }}=4.21 \text { to } 5
\end{aligned}
$$

\section{Reliability Analysis}

Table 3: Reliability Analysis

\begin{tabular}{|c|c|}
\hline Number of Statements & Alpha \\
\hline 18 & 0.83 \\
\hline
\end{tabular}

Table 3 indicated that alpha coefficient of the questionnaires dimensions was 0.83 (higher than 0.70) (Pallant, 2007). This result indicated to the reliability and validity of the questionnaires for using in the study.

\section{Results and Discussion}

The results involved three main stages. Descriptive analysis was used to discover participants' responses, variance analysis for respondents' answers and correlation analysis were conducted to examine the relationship between independent variables and dependent variable. The results obtained were computed and analyzed in the following tables.

Table 4: Demographic Data of Managers. 
Applying Outsourcing in Egyptian Hotels: A Field Study

- on a Sample of Five Star in Hotels Sharm El-Sheikh City

\begin{tabular}{|c|c|c|c|c|}
\hline \multirow{2}{*}{$\begin{array}{l}\text { Demograph } \\
\text { ic Data }\end{array}$} & \multirow{2}{*}{ Attribute } & \multicolumn{2}{|c|}{ Statistics } & \multirow[b]{2}{*}{$\begin{array}{r}\text { Ra } \\
\text { nk }\end{array}$} \\
\hline & & $\begin{array}{c}\text { Freq } \\
.\end{array}$ & $\%$ & \\
\hline \multirow[t]{4}{*}{$\begin{array}{l}\text { Educational } \\
\text { level }\end{array}$} & $\begin{array}{r}\text { Average degree } \\
\text { (Vocational/Secondary } \\
\text { School) }\end{array}$ & 53 & 13.6 & 4 \\
\hline & Institutional Degree & 80 & 20.5 & 2 \\
\hline & University Degree & 198 & 50.6 & 1 \\
\hline & $\begin{array}{r}\text { Postgraduate (Diploma - } \\
\text { Master - PhD) }\end{array}$ & 60 & 15.3 & 3 \\
\hline \multirow{3}{*}{$\begin{array}{c}\text { Years of } \\
\text { experience }\end{array}$} & Less than 10 years & 251 & 64.2 & 1 \\
\hline & From $10-15$ years & 112 & 28.6 & 2 \\
\hline & More than 15 years & 28 & 7.2 & 3 \\
\hline
\end{tabular}

As it can be observed from the previous table 4 that, among the 391 respondents, a high proportion of the tested sample $(50.6 \%)$ have a university educational degree, and $20.5 \%$ were have an institutional qualification, this was followed by manager whose have Postgraduates degree with 15.3\%. Managers with vocational/Secondary School degree was the smallest group and presented by $(13.6 \%)$. the results also showed that years of experience in the same position of the majority of the managers $(64.2 \%)$ were less than 10 years. While $28.6 \%$ was from $10-15$ years. Managers with more than 15 years of experience in the same position was the smallest group and presented by $7.2 \%$.

Table 5: Answers of respondents on the extent of applying outsourcing

\begin{tabular}{|c|c|c|}
\hline Answers & Freq. & \% \\
\hline Yes, totally & 122 & 31.3 \\
\hline Yes, partially & 269 & 68.7 \\
\hline Total & $\mathbf{3 9 1}$ & $\mathbf{1 0 0}$ \\
\hline
\end{tabular}


The result of this question showed that $68.7 \%$ of investigated hotels applied outsourcing partially (in some cases or in specific functions/activities), Meanwhile $31.3 \%$ applied outsourcing totally. These results indicate that the majority of the investigated hotels are concerned with applying outsourcing on their activities. This result in agreement with Hiamey and Amenumey (2013) who resulted that outsourcing considers as an adopted strategy which applied continually in hotels and will grow in the future.

Table 6: Ranking of the Investigated Dimensions.

\begin{tabular}{|c|c|c|c|c|c|c|c|c|}
\hline \multicolumn{4}{|c|}{ Current status } & \multirow[b]{2}{*}{ Dimension } & \multicolumn{4}{|c|}{ Prospective status } \\
\hline $\mathbf{R}$ & $\begin{array}{c}\text { p.valu } \\
\text { e }\end{array}$ & $(\mathrm{x} 2)$ & $\mathbf{x} \square$ & & $\mathbf{x} \square$ & $(\mathrm{x} 2)$ & $\begin{array}{c}\text { p.valu } \\
\text { e }\end{array}$ & $\mathbf{R}$ \\
\hline 7 & $0.00 *$ & 13.26 & 1.76 & $\begin{array}{l}\text { Food and } \\
\text { beverage }\end{array}$ & 2.39 & 8.33 & $0.02 *$ & 6 \\
\hline 2 & $0.00 *$ & 18.15 & 2.06 & Housekeeping & 2.73 & $\begin{array}{c}21.8 \\
3\end{array}$ & $0.00 *$ & 2 \\
\hline 1 & $0.05^{*}$ & 7.63 & 2.39 & Front office & 2.55 & 4.29 & $0.05 *$ & 4 \\
\hline 8 & 0.17 & 1.01 & 1.67 & $\begin{array}{c}\text { Human } \\
\text { resources }\end{array}$ & 2.13 & 6.22 & $0.04 *$ & 9 \\
\hline 4 & 0.33 & .963 & 1.95 & $\begin{array}{l}\text { Engineering } \\
\text { and } \\
\text { maintenance }\end{array}$ & 2.50 & .458 & 0.79 & 5 \\
\hline 3 & $0.00 *$ & 15.92 & 2.06 & $\begin{array}{l}\text { Information } \\
\text { technology }\end{array}$ & 2.25 & $\begin{array}{c}17.6 \\
2 \\
\end{array}$ & $0.00 *$ & 7 \\
\hline 5 & 0.29 & 2.48 & 1.79 & $\begin{array}{l}\text { Sales and } \\
\text { marketing }\end{array}$ & 2.56 & 5.19 & 0.15 & 3 \\
\hline 6 & $0.01 *$ & 5.37 & 1.78 & Security & 2.76 & $\begin{array}{c}16.7 \\
3\end{array}$ & $0.00 *$ & 1 \\
\hline 9 & $0.04 *$ & 6.74 & 1.33 & $\begin{array}{l}\text { Finance and } \\
\text { accounting }\end{array}$ & 2.17 & 7.98 & $0.03 *$ & 8 \\
\hline- & - & - & 1.87 & $\begin{array}{l}\text { Implementatio } \\
\text { n of }\end{array}$ & 2.45 & - & - & - \\
\hline
\end{tabular}




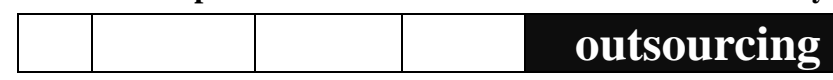

*Significant at $\mathrm{P} \leq 0.05, \mathbf{x} \square=$ Mean, $\mathrm{R}=$ Rank, $\mathrm{x} 2=$ Chi-Square

The results in table 6 depicted that, with regard to the current status of outsourcing in hotel departments, there was a significant difference among respondents' answers $(\mathrm{p}<0.05)$ in the majority of departments except for engineering and maintenance that p.value $=0.33$, sales and marketing that $\mathrm{p}$.value $=0.29$, and human resources that p.value $=0.17$. As with regard to the prospective status of outsourcing in hotel departments, there was a significant difference among respondents' answers ( $\mathrm{p}<$ 0.05 ) in the majority of departments except for engineering and maintenance that $\mathrm{p}$. value $=0.79$, sales and marketing that $\mathrm{p}$.value $=0.15$.

Data in table 6 indicated that currently hotels have outsourced to some extent their departments with average mean = 1.87. Front office department was the most in applying outsourcing on its activities/functions with mean $=2.39$. Meanwhile, the finance and accounting department was the least in applying outsourcing on its activities / functions with mean = 1.33. This result in contrast with Nicholson et al., (2006) result that accounting outsourcing is suitable for remote hotels due to the difficulty in recruiting and retaining the qualified accounting employees.

On other hand, hotel managers preferred to outsource their departments in the future with average mean $=2.45$. Security department was the most prospected to outsource on its activities/functions with mean $=2.76$. This result in agreement with Bolat and Yilmaz (2009) result's that security depa rtment is the most suitable to outsource in the hotels sector. Meanwhile, the human resources department was the least prospected to outsource on its activities / functions with mean $=2.13$.

Table 7: Respondents' answers on benefits of applying outsourcing. 


\begin{tabular}{|c|c|c|c|c|c|c|c|c|c|}
\hline \multirow{2}{*}{\multicolumn{2}{|c|}{ Statements }} & \multicolumn{5}{|c|}{ 5-Point Likert - Scale } & \multicolumn{3}{|c|}{ Statistics } \\
\hline & & & \multirow{2}{*}{\begin{tabular}{|l|}
2 \\
0
\end{tabular}} & \multirow{2}{*}{\begin{tabular}{|c|}
$\mathbf{3}$ \\
27 \\
\end{tabular}} & \multirow{2}{*}{\begin{tabular}{|r|}
$\mathbf{4}$ \\
12 \\
8
\end{tabular}} & \multirow{2}{*}{\begin{tabular}{|r|}
5 \\
23 \\
6
\end{tabular}} & \multirow{3}{*}{$\begin{array}{r}\mathrm{x} \square \\
4.5 \\
3\end{array}$} & \multirow{3}{*}{$\begin{array}{r}\text { SD } \\
.62 \\
3\end{array}$} & \multirow{3}{*}{$\frac{\mathbf{R}}{2}$} \\
\hline $\begin{array}{l}\text { Increasing the } \\
\text { flexibility and }\end{array}$ & $\begin{array}{c}\text { Fre } \\
\text { q. }\end{array}$ & & & & & & & & \\
\hline $\begin{array}{l}\text { downsize } \\
\text { responsibilities of } \\
\text { hotel } \\
\text { management. }\end{array}$ & $\%$ & 0 & 0 & 6.9 & $\begin{array}{l}32 . \\
7\end{array}$ & $\begin{array}{r}60 . \\
4\end{array}$ & & & \\
\hline \multirow{2}{*}{$\begin{array}{l}\text { Outsourcing is a } \\
\text { management } \\
\text { technique and } \\
\text { helps in } \\
\text { developing } \\
\text { managers' skills. }\end{array}$} & $\begin{array}{c}\text { Fre } \\
\text { q. }\end{array}$ & \begin{tabular}{|c|}
13 \\
6
\end{tabular} & $\begin{array}{c}17 \\
2\end{array}$ & 57 & 20 & 6 & \multirow[t]{2}{*}{$\begin{array}{c}1.9 \\
5\end{array}$} & \multirow[t]{2}{*}{$\begin{array}{c}.91 \\
4\end{array}$} & \multirow[t]{2}{*}{6} \\
\hline & $\%$ & $\begin{array}{l}34 \\
.8\end{array}$ & 44 & $\begin{array}{c}14 . \\
6\end{array}$ & 5.1 & 1.5 & & & \\
\hline \multirow{2}{*}{$\begin{array}{l}\text { Helps in manage } \\
\text { seasonality } \\
\text { problems and } \\
\text { fluctuation in } \\
\text { demand } \\
\text { effectively. }\end{array}$} & $\begin{array}{c}\text { Fre } \\
\text { q. }\end{array}$ & 3 & 18 & 48 & $\begin{array}{c}20 \\
0\end{array}$ & $\begin{array}{c}12 \\
2 \\
\end{array}$ & \multirow[t]{2}{*}{$\begin{array}{c}4.0 \\
7\end{array}$} & \multirow[t]{2}{*}{$\begin{array}{c}.82 \\
7\end{array}$} & \multirow[t]{2}{*}{3} \\
\hline & $\%$ & $\begin{array}{l}0 . \\
8\end{array}$ & 4.6 & $\begin{array}{c}12 . \\
3\end{array}$ & $\begin{array}{c}51 . \\
2\end{array}$ & $\begin{array}{c}31 . \\
2\end{array}$ & & & \\
\hline \multirow{2}{*}{$\begin{array}{l}\text { Increasing the } \\
\text { variety of } \\
\text { services which } \\
\text { contribute in } \\
\text { increasing guest } \\
\text { satisfaction. }\end{array}$} & $\begin{array}{c}\text { Fre } \\
\text { q. }\end{array}$ & 4 & 43 & $\begin{array}{c}23 \\
4 \\
\end{array}$ & 94 & 16 & \multirow[t]{2}{*}{$\begin{array}{c}3.1 \\
9\end{array}$} & \multirow[t]{2}{*}{$\begin{array}{c}.72 \\
1\end{array}$} & \multirow[t]{2}{*}{4} \\
\hline & $\%$ & 1 & 11 & $\begin{array}{c}59 . \\
8\end{array}$ & 24 & 4.1 & & & \\
\hline \multirow{2}{*}{$\begin{array}{l}\text { Reducing the } \\
\text { need of capital } \\
\text { which spent on } \\
\text { non-core } \\
\text { activities. }\end{array}$} & $\begin{array}{c}\text { Fre } \\
\text { q. }\end{array}$ & 0 & 0 & 16 & $\begin{array}{r}13 \\
3 \\
\end{array}$ & $\begin{array}{r}24 \\
2 \\
\end{array}$ & \multirow[t]{2}{*}{4.58} & \multirow[t]{2}{*}{.571} & \multirow[t]{2}{*}{1} \\
\hline & $\%$ & 0 & 0 & 4.1 & 34 & $\begin{array}{r}61 . \\
9\end{array}$ & & & \\
\hline $\begin{array}{l}\text { Converting fixed } \\
\text { costs to be }\end{array}$ & $\begin{array}{c}\text { Fre } \\
\text { q. }\end{array}$ & 77 & 93 & 39 & $\begin{array}{c}12 \\
9 \\
\end{array}$ & 53 & $\begin{array}{c}2.9 \\
7\end{array}$ & $\begin{array}{c}1.37 \\
9\end{array}$ & 5 \\
\hline
\end{tabular}


Applying Outsourcing in Egyptian Hotels: A Field Study

= on a Sample of Five Star in Hotels Sharm El-Sheikh City

\begin{tabular}{|l|r|c|c|c|c|c|c|c|c|}
\hline variable costs. & $\%$ & $\begin{array}{c}19 \\
7\end{array}$ & $\begin{array}{c}23 . \\
8\end{array}$ & 10 & 33 & $\begin{array}{c}13 . \\
6\end{array}$ & & & \\
\hline & Average Mean \\
\hline $\begin{array}{l}\text { N.B: 1="Strongly Disagree", 2=" Disagree, 3="Neutral", 4="Agree, 5= "Strongly Agree", SD, } \\
\text { "Standard Deviation". R=Rank, } \mathbf{x} \square=\text { Mean }\end{array}$
\end{tabular}

According to the results showed in Table 7. The respondents agreed on three statements from all statements about benefits of applying outsourcing which are arranged according to their means as follows:

- The statement of " Reducing the need of capital which spent on non-core activities." has got the highest percentage of agreement from the respondents at $(M e a n=4.58)$. This result agreed with Lamminmaki (2011), who referred that hotels rely to external companies in transportation services to avoid the cost of purchasing vehicles and maintenance costs in addition to drivers' problems.

- "Increasing the flexibility and downsize responsibilities of hotel management" at (Mean=4.53).

- "Helps in manage seasonality problems and fluctuation in demand effectively" at (Mean $=4.07$ ). This result matched with Dogerlioglu, (2012) result that seasonality and demand fluctuation are the main reasons to implement outsourcing practices as a significant factor to gain organization flexibility.

Meanwhile, the responses of managers were neutral with two statements which are arranged according to their means as follows:

- " Increasing the variety of services which contribute in increasing guest satisfaction " at (Mean=3.19).

- " Converting fixed costs to be variable costs " at (Mean=2.97).

On the other hand, their responses disagreed with the following statement as follows:

- " Outsourcing is a management technique and helps in developing managers' skills " at $($ Mean $=1.95)$. This result 
indicated that outsourcing have not impact in improving managers' skills.

Table 8: Respondents' answers on obstacles of applying outsourcing.

\begin{tabular}{|c|c|c|c|c|c|c|c|c|c|}
\hline & \multicolumn{5}{|c|}{ 5-Point Likert - Scale } & \multicolumn{3}{|c|}{ Statistics } \\
\hline & & \multirow{2}{*}{\begin{tabular}{|c|}
1 \\
66
\end{tabular}} & \multirow{2}{*}{\begin{tabular}{|c|}
2 \\
13 \\
4
\end{tabular}} & \multirow{2}{*}{$\begin{array}{c}3 \\
14 \\
9 \\
\end{array}$} & \multirow{2}{*}{\begin{tabular}{c|}
4 \\
42 \\
\end{tabular}} & \multirow{2}{*}{$\begin{array}{l}5 \\
0\end{array}$} & \multirow{2}{*}{$\begin{array}{c}\begin{array}{c}\text { Mea } \\
\text { n }\end{array} \\
2.43\end{array}$} & \multirow{2}{*}{$\begin{array}{c}\text { SD } \\
.89 \\
4\end{array}$} & \multirow{2}{*}{$\mathbf{R}$} \\
\hline $\begin{array}{r}\text { Lack of data } \\
\text { about }\end{array}$ & $\begin{array}{l}\text { Fr } \\
\text { eq. }\end{array}$ & & & & & & & & \\
\hline $\begin{array}{r}\text { outsourcing } \\
\text { and its } \\
\text { implementatio } \\
\text { n processes }\end{array}$ & $\%$ & $\begin{array}{c}16 . \\
9\end{array}$ & $\begin{array}{c}34 . \\
3\end{array}$ & $\begin{array}{c}38 . \\
1\end{array}$ & 10.7 & 0 & & & \\
\hline $\begin{array}{r}\text { Shortage of } \\
\text { outsourcing }\end{array}$ & $\begin{array}{l}\text { Fr } \\
\text { eq. }\end{array}$ & 6 & 41 & $\begin{array}{c}11 \\
4\end{array}$ & 168 & 62 & 3.61 & $\begin{array}{c}.92 \\
7\end{array}$ & 4 \\
\hline $\begin{array}{l}\text { suppliers in } \\
\text { the hotel } \\
\text { sector }\end{array}$ & $\%$ & 1.5 & $\begin{array}{c}10 . \\
5\end{array}$ & $\begin{array}{c}29 . \\
2\end{array}$ & 43 & $\begin{array}{c}15 . \\
9\end{array}$ & & & \\
\hline $\begin{array}{r}\text { Difficulty in } \\
\text { monitoring }\end{array}$ & $\begin{array}{l}\text { Fr } \\
\text { eq. }\end{array}$ & 0 & 0 & 0 & 118 & $\begin{array}{l}27 \\
3\end{array}$ & 4.70 & $\begin{array}{l}.46 \\
0\end{array}$ & \\
\hline $\begin{array}{r}\text { vendors and } \\
\text { controlling }\end{array}$ & $\%$ & 0 & 0 & 0 & & & & & 1 \\
\hline $\begin{array}{r}\text { over the } \\
\text { activities } \\
\text { which } \\
\text { outsourced }\end{array}$ & & & & & 30.2 & $\begin{array}{l}69 . \\
8\end{array}$ & & & \\
\hline $\begin{array}{r}\text { Supplier } \\
\text { interest }\end{array}$ & $\begin{array}{l}\text { Fr } \\
\text { eq. }\end{array}$ & 14 & 25 & 25 & 227 & $\begin{array}{c}10 \\
0\end{array}$ & 3.96 & $\begin{array}{c}.94 \\
8\end{array}$ & 3 \\
\hline $\begin{array}{l}\text { conflicts with } \\
\text { hotel policies }\end{array}$ & $\%$ & 3.6 & 6.4 & 6.4 & 58.1 & $\begin{array}{c}25 . \\
6\end{array}$ & & & \\
\hline $\begin{array}{l}\text { A possibility } \\
\text { of providing }\end{array}$ & $\begin{array}{l}\text { Fr } \\
\text { eq. }\end{array}$ & 0 & 3 & 27 & 110 & $\begin{array}{l}25 \\
1\end{array}$ & 4.56 & $\begin{array}{l}.65 \\
7\end{array}$ & 2 \\
\hline
\end{tabular}


Applying Outsourcing in Egyptian Hotels: A Field Study

= on a Sample of Five Star in Hotels Sharm El-Sheikh City

\begin{tabular}{|c|c|c|c|c|c|c|c|c|c|}
\hline $\begin{array}{r}\text { bad service or } \\
\text { unqualified } \\
\text { staff }\end{array}$ & $\%$ & 0 & 0.8 & 6.9 & 28.1 & $\begin{array}{l}64 . \\
2\end{array}$ & & & \\
\hline Non-direct & Fr & $\begin{array}{c}12 \\
3\end{array}$ & 17 & 60 & 28 & 9 & 2.05 & .98 & 6 \\
\hline $\begin{array}{r}\text { penalty } \\
\text { clauses and } \\
\text { negotiation } \\
\text { costs }\end{array}$ & $\%$ & $\begin{array}{c}31 . \\
5\end{array}$ & $\begin{array}{c}43 . \\
7\end{array}$ & $\begin{array}{c}15 . \\
3\end{array}$ & 7.2 & 2.3 & & & \\
\hline \multicolumn{7}{|c|}{ Average Mean } & 3.55 & - & - \\
\hline
\end{tabular}

N.B: 1="Strongly Disagree", 2=" Disagree, 3="Neutral", 4="Agree, 5= "Strongly Agree", SD,

"Standard Deviation", R=Ranking

With regard to the results showed in Table 8 . The respondents agreed on four statements from all statements about barriers of applying outsourcing which are arranged according to their means as follows:

- The statement of " Difficulty in monitoring vendors and controlling over the activities which outsourced " has got the highest percentage of agreement from the respondents at $($ Mean=4.70). This result in agreement with the result of Hiamey and Amenumey (2013) that loss of control considered as one of main reasons that make organizations not venturing into outsourcing.

- "A possibility of providing bad service or unqualified staff " at (Mean=4.56). This result agreed with the result of Hamzah et al., (2010), that organizations face some problems relevant to the poor quality of service in case of outsourcing.

- " Supplier interest conflicts with hotel policies " at (Mean $=3.96)$.

- "Shortage of outsourcing suppliers in the hotel sector" at $($ Mean= 3.61). 


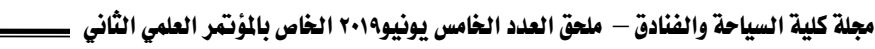

On the other hand, their responses disagreed with two statements which are arranged according to their means as follows:

- " Lack of data about outsourcing and its implementation processes " at (Mean=2.43).

- " Non-direct costs such as penalty clauses and negotiation costs " at $($ Mean= 2.05). This result was in contrast with the result of Hiamey and Amenumey (2013), that there are various hidden costs should took in consideration during venture to outsourcing such as; transaction costs during choosing suppliers, conversion costs during transferring activities from in-house to out-house and returning activities to in-house if suppliers did not provide the required services.

Table 9: Respondents' answers on factors affecting on outsourcing decision taking.

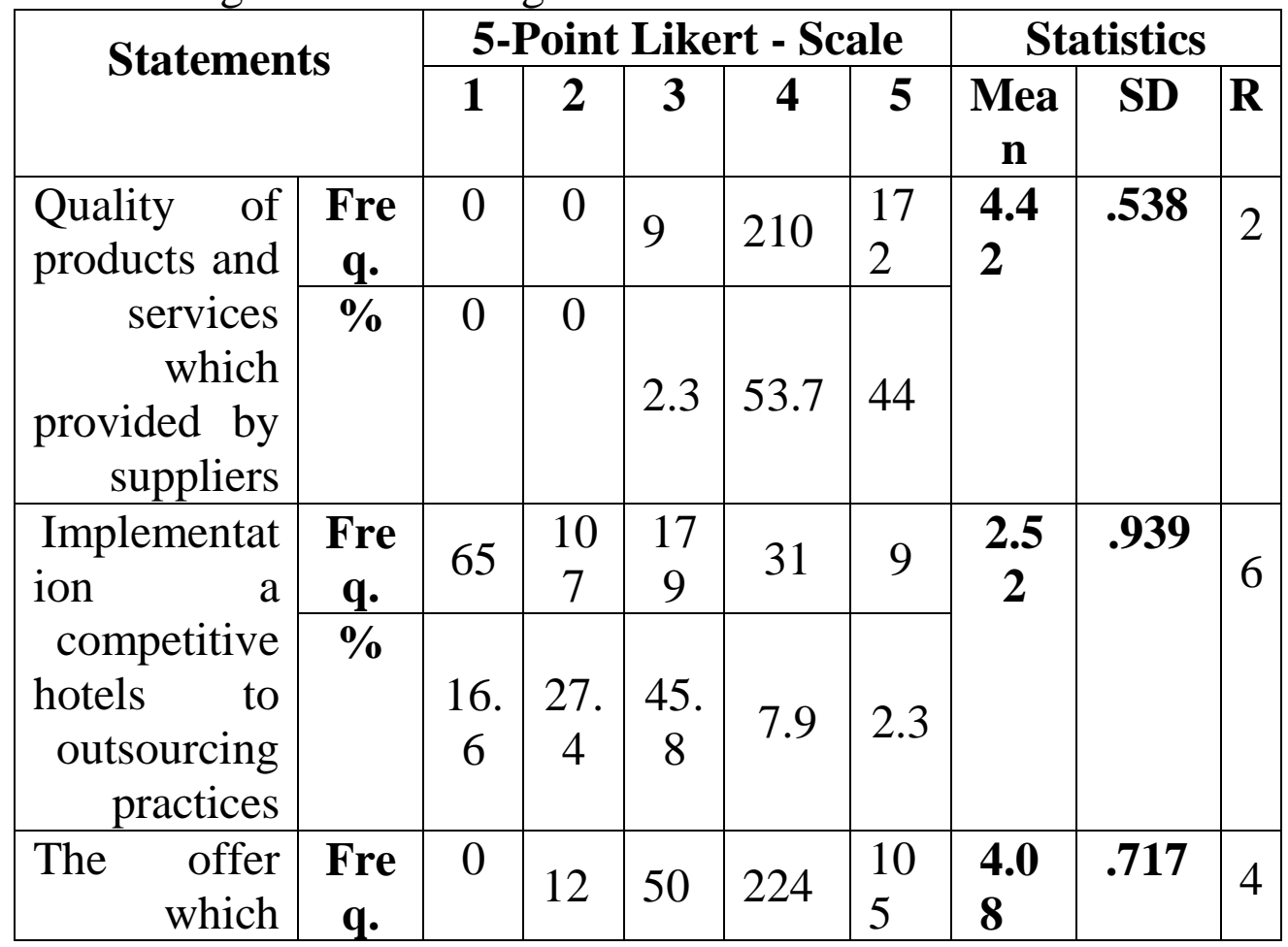


Applying Outsourcing in Egyptian Hotels: A Field Study

- on a Sample of Five Star in Hotels Sharm El-Sheikh City

\begin{tabular}{|c|c|c|c|c|c|c|c|c|c|}
\hline $\begin{array}{r}\text { provided in } \\
\text { contract } \\
\text { (e.g., price } \\
\text { and } \\
\text { duration) }\end{array}$ & $\%$ & 0 & 3.1 & $\begin{array}{l}12 . \\
8\end{array}$ & 57.3 & $\begin{array}{l}26 . \\
9\end{array}$ & & & \\
\hline \multirow{2}{*}{$\begin{array}{r}\text { Hotel } \\
\text { policies and } \\
\text { its culture }\end{array}$} & $\begin{array}{c}\text { Fre } \\
\text { a. }\end{array}$ & 0 & 0 & 3 & 84 & $\begin{array}{l}30 \\
4\end{array}$ & \multirow[t]{2}{*}{$\begin{array}{l}4.7 \\
7\end{array}$} & \multirow{2}{*}{\multicolumn{2}{|c|}{.439}} \\
\hline & $\%$ & 0 & 0 & 0.8 & 21.5 & $\begin{array}{l}77 . \\
7\end{array}$ & & & \\
\hline \multirow{2}{*}{$\begin{array}{r}\text { Expected } \\
\text { return from } \\
\text { outsourcing } \\
\text { application }\end{array}$} & $\begin{array}{c}\text { Fre } \\
\text { q. }\end{array}$ & 52 & 43 & 31 & 103 & $\begin{array}{c}16 \\
2\end{array}$ & \multirow[t]{2}{*}{$\begin{array}{c}3.7 \\
2\end{array}$} & \multirow[t]{2}{*}{$\begin{array}{c}1.43 \\
4\end{array}$} & 5 \\
\hline & $\%$ & $\begin{array}{c}13 . \\
3\end{array}$ & 11 & 7.9 & 26.3 & $\begin{array}{c}41 . \\
4\end{array}$ & & & \\
\hline \multirow{4}{*}{$\begin{array}{l}\text { The nature } \\
\text { of the } \\
\text { activity } \\
\text { (core or } \\
\text { non-core } \\
\text { activity) }\end{array}$} & $\begin{array}{c}\text { Fre } \\
\text { q. }\end{array}$ & 0 & 0 & 25 & 197 & $\begin{array}{l}16 \\
9\end{array}$ & \multirow[t]{3}{*}{4.37} & \multirow[t]{3}{*}{.601} & 3 \\
\hline & $\%$ & 0 & 0 & & & & & & \\
\hline & & & & 6.4 & 50.4 & $\begin{array}{l}43 . \\
2\end{array}$ & & & \\
\hline & \multicolumn{6}{|c|}{ Average Mean } & 3.98 & - & . \\
\hline
\end{tabular}

N.B: $1=$ "Strongly Disagree", 2=" Disagree, 3="Neutral", 4="Agree, 5= "Strongly Agree", SD, "Standard Deviation". R=Ranking

According to the results showed in Table 9. The respondents agreed on five statements from all statements about factors affecting on outsourcing decision taking which are arranged according to their means as follows:

- The statement of " Hotel policies and its culture " has got the highest percentage of agreement from the respondents at (Mean=4.77). This result agreed with Hiamey (2012) who postulated that in many outsourcing arrangements, the organization's fright of fail owing to cultural mismatch can constitute an impediment to implementing outsourcing. 
- "Quality of products and services which provided by suppliers" at $($ Mean=4.42).

- " The nature of the activity (core or non-core activity)" at (Mean =4.37). This result in agreement with (Yilmaz and BedÜk, 2014) recommendations that hotels should take in consideration the nature of activity before outsource it and do not in interest in cost reduction only. Core activity should be performed in-house to keep quality and increase guest satisfaction.

- " The offer which provided in contract" at (Mean=4.08).

- " Expected return from outsourcing application " at (Mean= 3.72).

On the other hand, their responses disagreed with the statement of " Implementation competitive hotels to outsourcing practices " at (Mean= 2.52). From this result it could concluded that, although hotels have the same characteristics, they differentiate in the nature of work. Therefore, implementation of competitive hotels to outsourcing not a standard or guide to the ability to apply outsourcing in their hotels.

Table 10: Differences among managers' responses towards applying outsourcing according to, educational level, and years of experience.

\begin{tabular}{|c|c|c|c|c|c|c|}
\hline \multirow{2}{*}{$\begin{array}{c}\text { Variable } \\
\text { s }\end{array}$} & \multirow[t]{2}{*}{ Categories } & \multicolumn{2}{|c|}{ Ranks } & \multicolumn{3}{|c|}{ Test Statistics } \\
\hline & & $\mathbf{N}$ & $\begin{array}{l}\text { Mean } \\
\text { Rank }\end{array}$ & $(\mathrm{x} 2)$ & $\begin{array}{c}\text { p.val } \\
\text { ue }\end{array}$ & Sig \\
\hline \multirow{4}{*}{$\begin{array}{l}\text { Education } \\
\text { al level }\end{array}$} & $\begin{array}{r}\text { Average degree } \\
\text { (Vocational/Secon } \\
\text { dary School) }\end{array}$ & 53 & 93.29 & \multirow{4}{*}{14.07} & \multirow{4}{*}{$0.00 *$} & \multirow{4}{*}{ H.S } \\
\hline & $\begin{array}{r}\text { Institutional } \\
\text { Degree } \\
\end{array}$ & 80 & 111.15 & & & \\
\hline & University Degree & $\begin{array}{c}19 \\
8\end{array}$ & 145.17 & & & \\
\hline & $\begin{array}{l}\text { Postgraduate } \\
\text { (Diploma - Master }\end{array}$ & 60 & 188.63 & & & \\
\hline
\end{tabular}


Applying Outsourcing in Egyptian Hotels: A Field Study

- on a Sample of Five Star in Hotels Sharm El-Sheikh City

\begin{tabular}{|c|c|c|c|c|c|c|}
\hline & $-\mathrm{PhD})$ & & & & & \\
\hline \multirow{3}{*}{$\begin{array}{c}\text { Years of } \\
\text { experienc } \\
\mathrm{e}\end{array}$} & Less than 10 years & 25 & 177.55 & \multirow{3}{*}{4.76} & \multirow{3}{*}{0.09} & \multirow{3}{*}{ N.S } \\
\hline & $\begin{array}{r}\text { From } 10-15 \\
\text { Years }\end{array}$ & $\begin{array}{c}11 \\
2\end{array}$ & 186.33 & & & \\
\hline & More than 15 years & 28 & 192.61 & & & \\
\hline
\end{tabular}

*Significant at $\mathbf{P} \leq \mathbf{0 . 0 5}$ N.S $=$ Non Significant H.S $=$ High Significant $\mathbf{x} 2=$ ChiSquare

As shown in Table 10, with regard to respondents' the result of Kruskal-Wallis test was used to examine the differences among respondents toward applying outsourcing according to educational level that p.value $=0.00$ which was less than the level of significance 0.05 . Thus, it concludes that there are differences among managers toward applying outsourcing according to educational level That is, once educational qualification increased. the tend to apply outsourcing increase. Hence, this hypothesis could be accepted.

In addition to that, the tabulated data in Table 10 cleared that, the result of the differences among respondents toward applying outsourcing according to years of experience that p.value $=0.09$ for years of experience which was higher than the level of significance 0.05 . Thus, it concludes that there are no differences among the sample responses of the study toward applying outsourcing according to years of experience. Hence, this hypothesis could be rejected.

Table 11: Correlation coefficient between dependent and independent variables:

\begin{tabular}{|c|c|c|}
\hline \multicolumn{2}{|c|}{ (Independent variables) } & $\begin{array}{c}\text { Dependent variable } \\
\text { (Outsourcing } \\
\text { Implementation) }\end{array}$ \\
\hline \multirow{2}{*}{$\begin{array}{c}\text { Benefits of } \\
\text { applying }\end{array}$} & Correlation & $.496^{*}$ \\
\hline & p-value & .003 \\
\hline
\end{tabular}




\begin{tabular}{|c|c|c|}
\hline outsourcing & $\mathrm{N}$ & 391 \\
\hline \multirow{3}{*}{$\begin{array}{l}\text { Barriers of } \\
\text { applying } \\
\text { outsourcing }\end{array}$} & Correlation & $.614^{*}-$ \\
\hline & p-value & .000 \\
\hline & $\mathrm{N}$ & 391 \\
\hline \multirow{3}{*}{$\begin{array}{c}\text { Factors affects } \\
\text { applying } \\
\text { outsourcing }\end{array}$} & Correlation & $.773^{*}$ \\
\hline & p-value & .042 \\
\hline & $\mathrm{N}$ & 391 \\
\hline
\end{tabular}

* = Highly significant at $\mathrm{P} \leq 0.05$

Taking a glance on the results in Table 11, it could be seen that there is a positive correlation among benefits of choosing outsourcing and implementing outsourcing. When the correlation coefficiency of spearman was 0.496. This positive correlation indicates that; whenever benefits increased, hotels desire to implement outsourcing increased, and the opposite is true. Thus, H.Corr.2.1 could be accepted.

In the same sense, there is a positive correlation among factors affects and implementing outsourcing. When the correlation coefficiency of spearman was 0.773 . This result indicates that; whenever factors affects have been handled, hotels desire to implement outsourcing increased, and the opposite is true. Thus, H.Corr.2.3 could be accepted.

On other hand, there is a negative correlation among implementations' barriers and implementing outsourcing. When the correlation coefficiency of spearman was $0.614^{-}$. This result indicates that; whenever barriers increased, hotels desire to implement outsourcing decreased, and the opposite is true. Thus, H.Corr.2.2 could be accepted.

Recommendations

Based upon both the literature reviewed and the findings, the following recommendations could be suggested: 
Applying Outsourcing in Egyptian Hotels: A Field Study

= on a Sample of Five Star in Hotels Sharm El-Sheikh City

1) Hotels should determine their core and non-core activities then take the right decision to outsource activities that will be effective if performed outside.

2) Hotels advised to outsource departments such as; security, housekeeping, and sales \& marketing.

3) It is recommended that hotels conduct with external supplies a long time outsourcing contracts to motivate them.

4) Two parties should identify all factors affect the deal (e.g. cost, service, time, quality) and agree on all clauses.

5) Suppliers recommended studying hotels' requirements accurately before contracting to ensure providing a proper service for hotels.

6) Government establishment should encourage the investment in supporting services to hotels sector such as; waste management, security, pests control and animation services.

${ }^{1}$ Assistant Lecturer , Hotels Studies Deparatment Faculty of Tourism and Hotels, Mansoura University 


\section{References}

- Abdullah, L. M., and Verner, J. M. (2012), " Analysis and Application of an Outsourcing Risk Framework", Journal of Systems and Software, 85 (1), pp. 1930- 1952

- Aman, A. and Abdul Rahman, E. Z. K. (2011), " Managing Relational Risks in Accounting Outsourcing: Experiences of Small Firm", World Applied Sciences Journal, 15 (1), pp. 56-62

- Aryee, S. (2011), "Hotel Maintenance Management (Strategic Practices in Hotel Operation)", Unpublished Master Thesis, Stockholm University, Sweden.

- Bolat, T., and Yilmaz, Ö. (2009), " The Relationship between Outsourcing and Organizational Performance: Is it Myth or Reality for the Hotel Sector?", International Journal of Contemporary Hospitality Management, 2 (1), pp. 7-23.

- Brinkkemper, S., and Jansen, S., (2012), " Collaboration in Outsourcing: A Journey to Quality", Macmillan Publishers Limited, United Kingdom. pp. 8-21.

- Calik, I., Batman, O., and Kingir, S. (2013), " Thoughts of City Hotels as Regards Outsourcing Strategies", Journal Of Tourism And Research, 2 (2), pp. 21-40.

- Chan, K. H. (2012), "Critical Factors in Contract Management" [Online].

Available from:

https://www.google.com.eg/url?sa=t\&rct=j\&q=\&esrc=s\&source=web\&c $\mathrm{d}=5 \& \mathrm{cad}=\mathrm{rja} \& u a c t=8 \& \mathrm{ved}=0$ ahUKEwivqOD10P3YAhWKlCwKHQv

QDpsQFghNMAQ\&url=https\%3A\%2F\%2Fwww.fig.net\%2Fpub\%2Ffig 2012\%2Fpapers\%2Fts01c\%2FTS01C_kh_5574.pdf\&usg=AOvVaw1EN 1AbrmdL_D8A5G7Assjx

[Accessed 22 June 2017]

- Dogerlioglu, O. (2012), " Outsourcing Versus In-house: A Modular Organization Perspective", The Journal of International Management Studies, 7 (1), pp. 22-30

- Dorasamy, M., Marimuthu, M., Jayabalan, J., Raman, M., and Kaliannan, M. (2010), " Critical Factors in Outsourcing of Accounting Functions in Malaysian Small Medium Sized Enterprises (SMEs)", Kajian Malaysia, 28 (2), pp. 39-46 
- Espino-Rodriguez, T. F., and Padron-Robaina, V., (2006), "A Review of Outsourcing from the Resource-Based View of the Firm", International Journal of Management Reviews, 8 (1), pp. 49-70

- Espino-Rodriguez, T. F., Lai, P. C., and Gil-Padilla, A. M. (2017), " Does Outsourcing Moderate the Effects of Asset Specificity on Performance? An Application in Taiwanese Hotels", Journal of Hospitality and Tourism Management, 31 (1), pp. 13-27

- Galahitiyawe, N. (2013), "Outsourcing Success: Determining its Critical Managerial Factors in Service Industry", Unpublished Doctor of Philosophy PhD, University of Malaya, Kuala Lumpur.

- Ghodeswar, B., and Vaidyanathan, J. (2008), "Business Process Outsourcing: An Approach to Gain Access to World-class Capabilities", Business Process Management Journal, 14 (1), pp. 23-38

- Hamzah, N., Aman, A., Maelah, R., Auzair S., and Amiruddin, R. (2010), " Outsourcing Decision Processes: A Case Study of a Malaysian Firm", African Journal of Business Management, 4 (15), pp. 3307-3314

- Hiamey, S. E. (2012), " Challenges of Hotel Outsourcing in Ghana: A Transaction Cost Perspective", African Journal of Hospitality, Tourism and Leisure. 2 (2), pp. 1-10

- Hiamey, S. E., and Amenumey, E. K. (2013), "Exploring Service Outsourcing in 3-5 Star Hotels in the Accra Metropolis of Ghana", Tourism Management Perspectives, 8 (1), pp. 9-17

- Kancharlan, M. (2007), " Turn on Lean Governance for Return on Outsourcing", [Online].

Available from:

https://link.springer.com/chapter/10.1007/978-3-540-75542-5_5 [Accessed 17 July 2017]

- Lamminmaki, D. (2003), "Outsourcing in the Hotel Industry: A Management Accounting Perspective", Unpublished Doctor of Philosophy $\mathrm{PhD}$, Griff University, Australia.

- Lamminmaki, D. (2009), " An Investigation of the Role Played by Frequency and Uncertainty in Hotel Outsourcing Decisions", International Journal of Services Technology and Management, 11 (1), pp. 182-201.

- Lamminmaki, D. (2011), " An Examination of Factors Motivating Hotel Outsourcing", International Journal of Hospitality Management, 30 (1), pp. 963-973 
- Linen, C. (2017), " Three Laundry Tips to Improve Guest Satisfaction in Hotels", [Online].

Available from:

http://www.crownlinen.net/blog/three-laundry-tips-to-improve-guestsatisfaction-in-hotels

[Accessed 15 October 2017]

- Mugassa, P. M. (2015), "An Analysis of Outsourcing Hotel Services in Tanzania", Journal of Hospitality and Tourism, 12 (1), pp. 51-66

- Nayak, N., Pai, A., Prabhu, N., and Khurana, A., (2016), " Manager's Perspective on Hotel Outsourcing Services", [Online].

Available from:

http://globalbizresearch.org/Malaysia_Conference_2016_July/docs/doc/ Management\%20\&\%20Marketing/KL626.pdf [Accessed 14 July 2017]

- Nicholson, B., Jones, J., and Espenlaub, S. (2006), " Transaction Costs and Control of Outsourced Accounting: Case Evidence from India", Management Accounting Research, 17 (1), pp. 238-258

- Pallant, J. (2007). "A Step by Step Guide to Data Analysis Using SPSS: Survival Manual". Third Edition. England, Open University Press: McGraw-Hill Education.

- Power, M. J., Desouza, K. C., and Bonifazi, C. (2006), "How to Implement a Successful Outsourcing Process" , Great Britain and the United States, London, Philadelphia.

- Promsivapallop, P. (2009), "A Critical Evaluation of Transaction Cost Economics Applied to Outsourcing in the Hotel Industry in Thailand", Unpublished Doctor of Philosophy PhD, University of Surrey.

- Promsivapallop, P., Jones, P., and, Roper, A. (2015), " Factors Influencing Hotel Outsourcing Decision in Thailand: Modification to the Transaction Costs Economics Approach", Journal of Hospitality \& Tourism Research, 39 (1), pp. 32-56

- Qu, W. G., Pinsonneault, A., and Oh, W. (2011), " Influence of Industry Characteristics on Information Technology Outsourcing", Journal of Management Information Systems, 27 (4) pp. 99-128

- Sani, A., Dezdar, S., and Ainin S. (2013), " Outsourcing Patterns among Malaysian Hotels" , International Journal of Business and Social Science, 4 (9), pp.133-144 
- Siew-Chen, S., and Seow-Voon, Y., (2016), " Exploring Human Resource Outsourcing Trends in Malaysia", Procedia - Social and Behavioral Sciences 224 ( 1 ), pp. 491- 498

- Sirec, K., Rebernik, M., and Hojnik, B. B. (2012), "Managing Tacit Knowledge in Strategic Outsourcing", University of Maribor, Faculty of Economics and Business, Slovenia.

- Smith, A. (2012), "The Pros and Cons of Outsourcing" Unpublished Master Thesis, University of Nevada, Los Anglos.

- Sriwongwanna, J. (2009), " Understanding the Impact of Outsourcing Human Resource Activities on Employee Attitudes and Behaviors", Unpublished Doctor of Philosophy PhD, Murdoch University.

- Trabulsi, L. (2017), "Key Considerations In Outsourcing Hotel Food \& Beverage" [Online].

Available from:

http://www.hotelexecutive.com/business_review/5348/keyconsiderations-in-outsourcing-hotel-food-beverage

[Accessed 17 May 2018]

- Vagadia, B. (2012), "Strategic Outsourcing: The Alchemy to Business Transformation in a Globally Converged World", Heidelberg: Springer.

- Vitasek, K., Ledyard, M., and Manrodt, K., (2013), "Vested outsourcing: Five Rules That Will Transform Outsourcing", Second Edition, Macmillan Publishers Limited.

- Yilmaz, A. M., and BedÜk, A. (2014), "Evaluation of the Effect of the Outsourcing on Resource Dependency and Transaction Cost Approach: A Research In Konya Oiz, Turkey", Procedia - Social and Behavioral Sciences, 109 (1), pp. $737-752$ 